\title{
HUBUNGAN PENGETAHUAN DAN SIKAP PERAWAT DENGAN TINDAKAN PENCEGAHAN INFEKSI DI RUANG ICU RUMAH SAKIT
}

\author{
The Relation of Knowledge and Attitude on Nurses \\ With Infection Controls in The ICU Ward Hospital
}

\author{
Suharto $^{1}$ dan Ratna Suminar ${ }^{2}$ \\ ${ }^{1}$ Dosen Tetap Yayasan Akper Kesdam I/BB Medan \\ ${ }^{2}$ Pegawai Rumah Sakit Putri Hijau Kesdam I/BB Medan \\ email: akperkesdam1bbmedan@yahoo.com
}

\begin{abstract}
Abstrak
Pengetahuan dan sikap Perawat dalam penggunaan alat pelindung diri pada saat melaksanakan tindakan keperawatan akan mengurangi resiko terjadinya pemularan infeksi di rumah sakit. Penelitian ini bertujuan untuk melihat hubungan pengetahuan dan sikap perawat tentang APD dengan tindakan pencegahan infeksi di ruang Intencif Care Unit (ICU). Metode penelitian ini yaitu penelitian observasional analitik, dengan desain cross sectional. Populasi dalam penelitian ini 23 Orang perawat ICU sebagai responden dengan menggunakan tehnik total sampling. Instrumen penelitian menggunakan kuesioner yang berisi pernyataan tentang pengetahuan, sikap dan tindakan pencegahan infeksi. Teknik analisis data yang digunakan adalah teknik analisis univariat dan bivariat (Chi Square). Pengujian Hipotesis dilakukan pada taraf signifikansi 0,05 atau $95 \%$.

Hasil penelitian ini menunjukan variabel yang memiliki hubungan dengan tindakan pencegahan infeksi pengetahuan $\rho=0,024<\alpha=0,05$ dan sikap $\rho=0,026<\alpha=0,05)$. dengan demikian dapat disimpulkan bahwa terdapat hubungan pengetahuan dan sikap perawat dengan tindakan pencegahan infeksi di ruang ICU. Oleh karena itu disarankan kepada manajemen rumah sakit agar meningkatkan pengetahuan dan sikap perawat ICU tentang manfaat APD dengan meningkatkan pengetahuan dan sikap perawat tentang APD melalui pendidikan dan pelatihan bagi perawat secara berkelanjutan.
\end{abstract}

Kata Kunci: Pengetahuan dan sikap, tindakan pencegahan infeksi

\begin{abstract}
The nurses of knowladge and attitude on protective presonal equipment uses during carry out of nursing intervention will be increased risk of hospital accuired infections. the research goals are observed the relation of knowledge and attitude on nurses with infection controls in the ICU ward hospital. the method of research is analitic observational research with use cross sectional design. research of polpulation are 23 nurses of intencif care unit ward and use total sampilng technic. the instrumen of research are quetsioners for knowladge, attitude and infection controls. The data obtained were analyzed through univariate analysis and bivariate analysis (Chi-square). The hypothesis was tested at the level of significance of $95 \%$ or $\alpha=0.05$.

The result of this study showed that the variables relation with infection controls were knowladge $(\mathrm{p}=$ $0.24)$, and attitude $(\mathrm{p}=0.026$. The conclusion drawn is that the realtion of knowledge and attitude on nurses with infection controls in the ICU ward hospital. The management of Putri Hijau Hospital, is suggested to make nurses increase of knowladge and attitude about PPE through the continues study.
\end{abstract}

Keywords: Knowledge and Attitude, Infection Controls 


\section{Pendahuluan}

Rumah sakit merupakan institusi pelayanan kesehatan yang didalamnya terdapat bangunan, peralatan, manusia, (petugas, pasien dan pengunjung) dan kegiatan pelayanan kesehatan, ternyata di samping dapat menghasilkan dampak positif berupa produk pelayanan kesehatan yang baik terhadap pasien, juga dapat menimbulkan dampak negatif berupa pengaruh buruk kepada manusia seperti pencemaran lingkungan, sumber penularan penyakit dan menghambat proses penyembuhan dan pemulihan penderita.

Selain potensi bahaya berupa penyakit infeksi yang umumnya berasal dari pasien, rumah sakit juga mempunyai potensi bahaya lain yang mempengaruhi situasi dan kondisi di rumah sakit yaitu peledakan, kebakaran, kecelakaan yang berhubungan dengan instalasi listrik, radiasi, bahan - bahan kimia berbahaya, gas anestesi, gangguan psikososial, dan ergonomi (Aditama, 2006).

Kejadian infeksi yang tinggi di rumah sakit merupakan indikator pentingnya suatu usaha pengendalian infeksi dengan menerapkan standar kewaspadaan infeksi (Standard precaution). Standard Precaution pada dasarnya merupakan transformasi dari universal precaution, yaitu suatu bentuk precaution pertama yang bertujuan untuk mencegah infeksi nosokomial (Kathryn, 2004).

Dalam meningkatkan upaya tindakan pencegahan infeksi, diperlukan pengetahuan dan sikap perawat dalam penggunaan alat pelindung diri (APD) agar terhindar dari risiko penularan penyakit baik dari pasien ke perawat maupun sesama pasien.

Perawat mempunyai risiko yang tinggi untuk menerima pajanan penyakit akibat adanya infeksi yang dapat mengancam keselamatannya saat berkerja. WHO mencatat Tahun 2004 kasus infeksi nosokomial didunia berupa penularan hepatitis B sebayak 66.000 kasus, hepatitis C sebanyak 16.000 dan 10.000 kasus penularan HIV. Hal ini tidak menutup kemungkinan bagi petugas kesehatan dapat terinfeksi. Telah diperkirakan terjadi penularan hepatitis B (39\%), hepatitis C (40\%), dan HIV (5\%) pada tenaga kesehatan diseluruh dunia. Menurut Maja (2009) dalam Precautions used by occupational health nursing students during clinical plancements menjelaskan terkait penerapan APD. Penelitian ini menunjukan tingginya tingkatan penerapan mencuci tangan, penggunaan APD dan tingkat pelatihan yang lebih dari $80 \%$ responden. Selain itu, penelitian ini juga menjelaskan bahwa $17,8 \%$ respondennya gagal menggunakan APD ketika praktek akibat terbatasnya jumlah APD yang disediakan di tempat praktek. Selain itu juga menjelaskan bahwa sikap negatif yang ditunjukan dengan menolak menggunakan APD karena merasa tidak nyaman mendorong responnya untuk berperilaku tidak menggunakan APD. sedangkan penelitian Habni (2009) yang berjudul Perilaku Perawat dalam Pencegahan Infeksi Nosokomial di Rumah Sakit Umum Pusat Haji Adam Malik Medan dalam hal pencegahan infeksi nosokomial yang melibatkan perawat di ruang rawat inap, IGD, ICU, dan rawat jalan sebagai responden. Hasil penelitiannya didapatkan $76 \%$ perawat yang tidak mendapatkan pelatihan tentang pencegahan infeksi nosokomial cenderung memiliki perilaku yang buruk dalam melakukan pencegahan infeksi nosokomial.

Pengetahuan perawat mengenai pencegahan infeksi dengan melakukan tindakan septik dan aseptik serta kemampuan untuk mencegah transmisi infeksi di rumah sakit adalah tindakan pertama dalam pemberian pelayanan yang bermutu. Hal ini dapat diupayakan melalui peningkatan sikap perawat tentang kesadaran menggunakan APD dalam melakukan setiap tindakan keperawatan. Menurut penelitian Nasution (2011) terhadap 34 orang petugas kesehatan ruang ICU di dua rumah sakit didapatkan hasil perilaku terhadap tindakan dan sikap petugas kesehatan terhadap APD mayoritas sedang $(60 \%)$.

Perawat dalam memberikan pelayanan kesehatan kepada pasien harus mempunyai pengetahuan dan sikap yang baik tentang penggunaan APD dalam setiap pemberian pelayanan kesehatan pada pasien. mengingat fungsi APD memiliki peran yang penting dalam upaya mengeliminir transmisi agent penyakit infeksi baik dari lingkungan rumah sakit, dari pasien ke perawat maupun dari pasien ke pasien lainnya maupun infeksi yang terjadi pada pasien itu sendiri. Untuk dapat menggunakan APD secara benar harus didukung oleh pengetahuan dan sikap yang baik, dari segi pengetahuan perawat harus bisa memahami potensi risiko bahaya infeksi dan pintu masuk dari transmisi agent infeksi tersebut sehingga dapat memilih jenis dan bahan APD yang sesuai dengan potensi bahaya yang ada. Sedangkan dari segi sikap perawat harus didukung dengan perilaku yang baik terkait dengan penggunaan APD seperti kepatuhan dalam menggunakan APD dengan benar pada saat melakukan tindakan keperawatan dan kesadaran untuk merawat APD.

Berdasarkan uraian diatas maka penelitian ini penting dilakukan karena masalah infeksi yang di dapat di rumah sakit akan berpengaruh pada mutu pelayanan kesehatan yang diberikan rumah sakit terhadap psien. 
Berdasarkan data tersebut diatas dan pengalaman peneliti selama berdinas di Rumah Sakit Tk II Putri Hijau masih ada perawat ICU yang kurang memahami pentingnya penggunaan APD dalam melaksanakan setiap tindakan perawatan pada pasien dan adanya sikap yang kurang adaptif terhadap APD dalam upaya mengurangi risiko terjadinya infeksi di ruang ICU, sehingga penulis tertarik untuk meneliti bagaimana hubungan pengetahuan dan sikap perawat tentang APD di Ruang ICU Rumah Sakit Tk II Putri Hijau.

\section{Tinjaun Pustaka \\ Pengetahuan}

Pengetahuan merupakan hasil dari tahu dan terjadi setelah orang melakukan pengindraan terhadap suatu objek tertentu. Pengindraan meliputi penglihatan, pendengaran, penciuman, rasa dan raba. Pengetahuan merupakan bagian dari perilaku yang tidak bisa diamati secara langsung oleh orang lain karena masih terjadi didalam diri manusia itu sendiri (covert behavior).

Pengetahuan yang tercakup dalam domain kognitif mempunyai 6 (enam) tingkatan (Notoadmodjo, 2007) .

\section{Tahu (know)}

Tahu diartikan sebagai mengingatkan suatu materi yang telah dipelajari sebelumnya. Termasuk kedalam tingkat ini adalah mengingat kembali sesuatu yang spesifik dari seluruh bahan yang dipelajari atau rangsangan yang telah diterima. Oleh sebab itu tahu ini merupakan tingkat pengetahuan yang paling rendah. Kata kerja untuk mengukur bahwa orang tahu tentang apa yang dipelajari antara lain menyebutkan, menguraikan, mendefenisi kan, menyatakan dan sebagainya.

2. Memahami (comprehension)

Memahami diartikan sebagai suatu kemampuan untuk menjelaskan secara benar tentang objek yang diketahui dan dapat menginterfrestasikan materi tersebut secara benar. Orang yang paham terhadap objek atau materi harus dapat menjelaskan, menyebutkan contoh, menyimpulkan, meramalkan dan sebagainya terhadap objek yang dipelajari.

3. Aplikasi (aplication)

Aplikasi diartikan sebagai kemampuan untuk menggunakan materi yang telah dipelajari pada situasi atau kondisi yang sebenarnya. Aplikasi disini dapat diartikan sebagai penggunaan hukum-hukum, rumus, metode, prinsip dan sebagainya dalam konteks atau situasi yang lain.
4. Analisis (analysis)

Analisis adalah suatu kemampuan untuk menjabarkan materi atau suatu objek kedalam komponen-komponen, tetapi masih dalam struktur organisasi, dan masih ada kaitannya satu sama lain. Misalnya mampu membedakan, memisahkan, mengkelompokan dan sebagainya.

5. Sintesis (synthesis)

Sintesis menunjukan kepada suatu kemampuan untuk meletakan atau menghubungkan bagian-bagian dalam suatu bentuk keseluruhan yang baru. Dengan kata lain sintesis adalah suatu kemampuan untuk menyusun formasi baru dari formulasiformulasi yang ada. Misalnya dapat menyusun, merencanakan, meringkaskan menyesuaikan dan sebagainya terhadap suatu teori atau rumusan-rumusan yang telah ada.

6. Evaluasi (evaluation)

Evaluasi ini berkaitan dengan kemampuan untuk melakukan penilaian terhadap suatu materi atau objek. Penilaian-penilaian itu berdasarkan suatu kriteria yang ditentukan sendiri atau menggunakan kriteria-kriteria yang telah ada. Misalnya, dapat membedakan antara anak yang gizi baik dengan gizi kurang

\section{Sikap}

Sikap merupakan suatu pandangan, tetapi dalam hal itu masih berbeda dengan suatu pengetahuan yang dimiliki orang. Pengetahuan mengenai suatu objek tidak sama dengan sikap terhadap objek itu. Pengetahuan saja belum menjadi penggerak seperti halnya pada sikap. Pengetahuan mengenai suatu objek baru menjadi sikap apabila pengetahuan itu disertai kesiapan untuk bertindak sesuai dengan pengetahuan terhadap objek tersebut. Sikap mempunyai segi motivasi, berarti segi dinamis mengenai suatu tujuan, berusaha mencapai suatu tujuan. Sikap dapat merupakan suatu pengetahuan tetapi pengetahuan yang disertai kesediaan kecenderungan bertindak sesuai dengan pengetahuan itu (Purwanto, 1998). menurut Allport (1935) yang dikutip oleh (Wawan dan Dewi, 2011) sikap adalah kondisi mental dan neural yang diperoleh dari pengalaman yang mengarahkan dan secara dinamis mempengaruhi respon-respon individu terhadap semua objek dan situasi yang terkait.

Menurut Alport (1954) yang dikutip oleh Notoatmodjo (2007) bahwa sikap mempunyai 3 komponen pokok yaitu: (1) kepercayaan (keyakinan), ide dan konsep terhadap suatu objek, (2) Kehidupan emosional atau evaluasi terhadap suatu objek dan (3) Kecenderungan untuk bertindak (tend to behave). 
Seperti halnya dengan pengetahuan, sikap terdiri dari berbagai tindakan, yaitu (Notoatmodjo, 2007):

a. Menerima (receiving), diartikan bahwa orang (subjek) mau dan memperhatikan stimulus yang diberikan (objek).

b. Merespon (responding), berarti memberi jawaban apabila ditanya, mengerjakan dan menyelesaikan tugas yang diberikan adalah suatu indikasi dari suatu sikap.

c. Menghargai (valuing), artinya mengajak orang lain untuk mengerjakan atau mendiskusikan suatu masalah adalah suatu indikasi sikap tingkat ketiga. Bertanggung jawab (responsible), artinya bertanggung jawab atas yang telah dipilihnya dengan segala resikonya merupakan sikap yang paling tinggi

\section{Tindakan pencegahan}

Menurut Tietjen dkk (2004), Sebagian besar infeksi ini dapat dicegah dengan strategi yang telah tersedia secara relatif murah, yaitu :

a. Mentaati praktek pencegahan infeksi yang dianjurkan, terutama kebersihan dan kesehatan tangan serta pemakaian sarung tangan,

b. Memperhatikan dengan seksama proses yang telah terbukti bermanfaat untuk dekontaminasi dan pencucian peralatan dan benda lain yang kotor, diikuti dengan sterilisasi atau disinfeksi tingkat tinggi; dan

c. Meningkatkan keamanan dalam ruang operasi dan area beresiko tinggi lainnya dimana kecelakaan perlukaan yang sangat serius dan paparan pada agen penyebab infeksi sering terjadi.

Tidak semua infeksi nosokomial dapat dicegah. Contohnya, beberapa merupakan pengaruh bertambahnya usia, penyakit kronis seperti diabetes yang tidak terkontrol, penyakit ginjal berat, kekurangan gizi berat, perawatan dengan obat-obatan tertentu (separti antimikrobia, kortikosteroid, dan agen-agen lain yang dapat menurunkan imunisasi), bertambahnya dampak AIDS (misalnya, infeksi oportunistik) dan radiasi. Tietjen dkk (2004).

\footnotetext{
Alat Pelindung Diri (APD)

Alat pelindung diri merupakan peralatan yang digunakan tenaga kesehatan untuk melindungi diri dan mencegah infeksi nosokomial. Tujuan penggunaan APD untuk melindungi kulit dan selaput lendir tenaga kesehatan dari pajanan semua cairan tubuh dari kontak langsung dengan pasien (Depkes, 2003) APD perawat ketika praktek terdiri dari sarung tangan, alat pelindung wajah, penutup kepala, gaun pelindung atau
}

apron, alas kaki atau sepatu (potter \& perry, 2005)

\section{Sarung tangan}

Pemakaian sarung tangan merupakan bagian penting dari standar precaution bagi perawat yang sering berinteraksi dengan pasien maupun alat-alat yang terkontaminasi. Sarung tangan dapat membantu perawat untuk melindungin tangan dari kontak dengan darah, semua jenis cairan tubuh, sekret, kulit yang tidak utuh, selaput lendir pasien dan benda yang terkontaminasi (Depkes RI, 2003). Hal yang perlu diperhatikan dalam penggunaan sarung tangan (Depkes RI, 2003) :

a. Mencuci tangan dengan sabun sebelum dan sesudah menggunakan sarung tangan,

b. Mengganti sarung tangan jika berganti pasien atau sobek,

c. Mengganti sarung tangan segera setelah melakukan tindakan,

d. Menggunakan sarung tangan saat menggunakan alat nonkontaminasi,

e. Menggunakan satu sarung tangan untuk satu prosedur tindakan,

f. Menghindari kontak dengan benda-benda selain dalam tindakan,

g. Menghindari penggunaan atau mendaur ulang kembali sarung tangan sekali pakai.

2. Alat pelindung wajah

Alat pelindung wajah merupakan peralatan wajib perawat untuk menjaga keamanan dirinya dalam menjalankan asuhan keperawatan. Alat pelindung diri wajah dapat melindungi selaput lendir dibagian mulut, hidung dan mata perawat terhadap resiko percikan darah maupun cairan tubuh manusia. Alat pelindung wajah terdiri dari masker dan kacamata pelindung (Depkes,2003). Kedua jenis alat pelindung diri tersebut dapat digunakan terpisah maupun bersamaan sesuai dengan jenis tindakan.

Masker bagian alat pelindung muka khususnya untuk melindungi mulut dan hidung perawat ketika berinteraksi dengan pasien. Masker dianjurkan untuk selalu digunakan perawat ketika melakukan tindakan dengan semua pasien khususnya pasien TB. (Depkes, 2003). Hal ini diharapkan mampu melindungi perawat terhadap penularan melalui udara. Secara umum masker dibagi menjadi dua jenis yaitu masker standar dan masker khusus.Beberapa hal yang perlu diperhatikan ketika menggunakan masker ( WHO, 2004):

a. Memasang masker sebelum memasang sarung tangan,

b. Tidak dianjurkan menyentuh masker ketika menggunakannya, 
c. Mengganti masker ketika kotor dan lembab,

d. Melepas masker dilakukan setelah melepas sarung tangan dan cuci tangan,

e. Tidak membiarkan masker menggantung dileher,

f. Segera melepaskan masker dilakukan jika tidak digunakan

g. Tidak dianjurkan menggunakan kembali masker sekali pakai.

Kacamata sebagai bagian dari APD yang bertujuan melindungi mata. Kacamata digunakan untuk mencegah masuknya cairan darah maupun cairan tubuh lainnya pada mata (Potter dan perry, 2005).

\section{Penutup kepala}

Penutup kepala sebagai bagian dari standard precaution memilikin fungsi dua arah. Fungsi pertama, penutup kepala membantu mencegah terjadinya percikan darah maupun cairan pasien pada rambut perawat. Selain itu, penutup kepala dapat mencegah jatuhnya mikroorganisme yang ada di rambut maupun kulit kepala ke area steril (Depkes, 2003). Kedua fungsi tersebut sangat penting untuk diperhatikan oleh perawat.

\section{Gaun pelindung}

Gaun pelindung atau baju kerja atau celemek dapat memberikan manfaat bagi perawat untuk melindungi kulit dan pakaian dari kontaminasi cairan tubuh pasien. Gaun pelindung wajib digunakan ketika melakukan tindakan irigasi, menangani pasien dengan perdarahan, melakukan pembersihan luka, maupun tindakan lainnya yang terpapar dengan cairan tubuh pasien (Depkes, 2003).

Gaun pelindung terdiri dari beberapa macam berdasarkan pada kegunaannya, Terdapat dua jenis gaun pelindung yaitu gaun pelindung steril dan non steril (Depkes, 2003).

Perawat sebagai pemberi asuhan keperawatan perlu mengetahui penggunaan gaun pelindung secara benar. Penggunaan gaun pelindung secara benar dapat melindungi perawat dari bahaya infeksi. Hal-hal yang perlu diperhatikan perawat dalam penggunaan gaun pelindung meliputi (Rosdahl \&Merry, 2008):

a. Bagian dalam gaun adalah bersih dan bagian luarnya adalah yang nantinya harus dijaga (sesuai dengan jenis gaunnya),

b. Ukuran gaun perlindung harus cukup panjang dan dapat menutupi seragam perawat bagian depan dan belakang namun tidak menutupi lengan,

c. Jika menggunakan seragam lengan panjang, seragam harus digulung diatas siku dan perawat baru menggunakan gaun pelindung, d. Ketika hendak melepaskan gaun pelindung, cara melepaskan adalah dari dalam keluar untuk mencegah kontaminasi cairan dengan seragam,

e. Setelah melepas gaun jangan lupa untuk selalu mencuci tangan sebelum melakukan aktivitas lain.

\section{Alas kaki (sepatu)}

Alas kaki merupakan bagian dari APD yang perlu untuk digunakan. Alas kaki melindungi perawat ataupun petugas kesehatan terhadap tumpuhan atau percikan darah maupun cairan tubuh yang lain. Penggunaan alas kaki juga bertujuan untuk mencegah kemungkinan tusukan benda tajam maupun kejatuhan alat kesehatan (Depkes, 2003). Menurut Rosdahl \& Merry (2008) yang dikutip Putra (2012), standar alas kaki yang tertutup seluruh ujung jari dan telapak kaki serta terbuat dari bahan yang mudah dicuci dan bahan tusukan. Penggunaan alas kaki termsuk juga sepatu yang dipakai sehari-hari harus memenuhi syarat dan juga penggunaan sepatu khusus seperti sepatu khusus diruang tertentu misal ruang operasi, ICU, isolasi, ruang bersalin, ruang pemulasaraan jenazah (Depkes, 2003).

\section{Pencegahan ninfeksi}

Pada tahun 1995 Center of disease control and prevention (CDC) menetapkan bentuk pencegahaan: tindakan pencegahaan standart, didesain untuk semua perawatan pasien dirumah sakit tanpa memperhatikan diagnosa mereka atau status infeksi sebelumnya. Tindakan pencegahan transmisi, yang dibagi dalam katergori udara, doplet dan kontak dan digunakan pada pasien yang diketahui atau dicurigai terinfeksi atau terkolonisasi patogen secara epidemiologis dapat ditularkan melalui udara dan kontak. Tindakan pencegahan standart diterapkan untuk darah, sekresi,dan cairan tubuh tanpa memperhatikan apakah mengandung darah yang terlihat dan membran mukosa. Tindakan pencegahan berdasarkan transmisi dirancang untuk pasien yang telah didokumentasikan mengalami atau dicurigai terinfeksi yang dapat ditransmisikan melalui udara atau droplet, organisme yang secara epidemiologi, termasuk isolasi penyakit menular (Swearing, 2000).

Menurut Potter dan Perry (2005) dalam upaya pencegahan dan pengendalian infeksi harus disesuaikan dengan rantai terjadinya infeksi nosokomial sebagai berikut menurut yaitu:

a. Kontrol atau eleminasi agen infeksius

Pembersihan, desinfeksi dan sterilisasi terhadap objek yang terkontaminasi secara signifikan mengurangi dan sering kali 
memusnahkan mikrootganisme. Pembersihan adalah membuang sampah material asing seperti kotoran dan materi organik dari suatu objek. Disinfektan menggambarkan proses yang memusnakan banyak atau semua organisme dan pengecualian spora bakteri, dari objek yang biasanya menggunakan desinfektan kimia. Sterilisasi adalah pemusnahan seluruh mikroorganisme termasuk spora (Potter dan Perry (2005)

\section{b. Kontrol atau eleminasi reservoir}

Untuk mengeleminasi reservoir perawat harus membersihkan cairan tubuh, drainase, atau larutan yang dapat merupaka tempat mikroorganisme. Perawat juga membuang sampah dengan hati-hati alat yang terkontaminasi materi infeksius. Semua institusi kesehatan harus memiliki pedoman untuk membuang materi sampah infeksius menurut kebijakan lokal dan negara (Potter dan Perry, 2005)

\section{c. Kontrol terhadap portal keluar}

Perawat mengikut peraktek pencegahan dan kontrol untuk meminimalkan atau mencegah organisme yang keluar melalui saluran pernafasan, perawat harus selalu menghindari berbicara langsung menghadap pasien, perawat harus selalu menggunakan sarung tangan sekali pakai bila menangani eksudat. Masker, gaun dan kacamata jika terdapat kemungkinan adanya percikan dan kontak cairan. Perawat yang demam ringan namun tetap bekerja harus memakai masker, khususnya bila mengganti balutan atau melakukan prosedur steril. Perawat juga bertanggung jawab mengajarkan klain untuk melindungi orang lain pada saat bersin dan batuk. Cara lain mengontrol keluarnya mikroorganisme adalah penanganan yang hati-hati terhadap eksudat. Cairan yang terkontaminasi dapat dengan mudah terpecik saat dibuang ditoilet atau bak sampah (Potter dan Perry, 2005).

\section{d. Pengendalian penularan}

Pengendalian efektif terhadap infeksi mengharuskan perawat harus tetap waspada tentang jenis penularan dan cara mengontrolnya. Bersihkan dan sterilkan semua peralatan yang reversibel. Tehnik yang paling penting adalah mencuci tangan dan aseptik. Untuk mencegah penularan mikroorganisme melalui kontak tidak langsung, peralatan dan bahan yang kotor harus dijaga supaya tidak bersentuhan dengan baju perawat. Tindakan yang salah sering dilakukan adalah mengangkat linen yang kotor langsung dengan tangan mengenai seragam (Potter dan Perry, 2005).

e. Kontrol terhadap portal masuk
Dengan mempertahankan integritas kulit dan membran mukosa menurunkan kemungkinan penjamu. Tenaga kesehatan harus berhati-hati terhadap resiko jaru suntik. Perawat harus menjaga kesterilan alat dan tindakan invasif klien, tenaga kesehatan dan tenaga kebersihan beresiko mendapat infeksi dari tusukan jarum secara tidak sengaja. Pada pembersihan luka perawat menyeka bagian dalam dulu kemudian bagian luar (Potter dan Perry, 2005).

f. Perlidungan terhadap penjamu yang rentan

Tindakan isolasi atau barrier termasuk menggunakan gaun, sarung tangan, kacamata dan masker serta alat pelindung lainnya. Perawat semua klien kewaspadaan berdasrakan penularan perlukaan untuk mengurangi resiko infeksi untuk klien tanpa memandang jenis sistem isolasi, perawat harus mengikuti prinsip dasar yaitu: harus mencuci tangan sebelum masuk dan meninggalkan ruangan isolasi, benda yang terkontaminasi harus dibuang untuk mencegah penyebaran mikroorganisme, pengetahuan tentang proses penyakit dan jenis penularan infeksi harus diaplikasikan pada saat menggunakan barrier pelindung, semua orang yang kemungkinan terpapar selama perpindahan klien diluar kamar isolasi harus dilindungi. Lingkungan yang protektif yang digunakan untuk isolasi dapat memiliki tekanan udara yang negatif untuk mencegah partikel infeksius mengalir keluar dari ruang. Ada juga kamar harus dengan tekanan aliran posotif digunakan pada pasien yang rentan seperti resepien transplantasi (Potter dan Perry, 2005).

\section{g. Perlindungan bagi perawat}

Perlindungan barrier harus sudah tersedia bagi pekerja yang memasuki kamar isolasi, menggunakan gaun, sarung tangan, masker dan kacamata pelindung. Perawat mengenakan sarung tangan bila resiko terpapar materi infeksius, khususnya sarung tangan direkomendasikan saat perawat pada tergores atau luka pada kulit saat melakukan fungsi vena, karena mereka beresiko terkena tumpukan darah atau cairan tubuh lainnya pada tangan, dan bila mereka kurang pengalaman. CDC Lebih lanjut merekomendasikan bahwa sarung tangan hanya digunakan sekali pakai (Potter dan Perry, 2005).

\section{Perawat}

Menurut Kepmenkes RI No.1239 tahun 2001 tentang Registrasi dan Praktek Perawat, perawat adalah seseorang yang telah lulus pendidikan perawat, baik di dalam maupun di luar negeri sesuai dengan ketentuan peraturan perundanganundangan yang berlaku. Menurut Kusnanto 
(2004) dalam melaksanakan praktek keperawatan, perawat juga dituntut melakukan peran dan fungsi sebagaimana yang diharapkan oleh profesi dan masyarakat sebagai pengguna jasa pelayanan keperawatan. Menurut Kusnanto (2004) peran merupakan tingkah laku yang diharapkan oleh orang lain terhadap seseorang, sesuai kedudukannya dalam suatu sistem. Peran perawat dipengaruhi oleh keadaan sosial baik dari dalam maupun dari luar profesi keperawatan dan bersifat konstan. Doheny (1982) (dalam Kusnanto, 2004) mengidentifikasi beberapa peran perawat professional meliputi: Care giver, Client advocate, Counsellor, Educator, Collaborator, Coordinator, Change agent, Consultant,

\section{Metode Penelitian}

Jenis penelitian yang digunakan dalam penelitian ini adalah analitik dengan desain cross sectional dengan tujuan untuk melihat hubungan pengetahuan dan sikap perawat ICU tentang APD dengan tindakan pencegahan infeksi pada perawat di Rumah Sakit Tk II Putri Hijau

Lokasi yang digunakan dalam penelitian ini adalah ruang ICU Rumah sakit Tk II Putri Hijau.

Penelitian ini di lakukan mulai bulan Januari sampai Maret 2016. Sampel dalam penelitian ini adalah perawat yang bertugas di Ruang ICU Rumah Sakit Tk II Putri Hijau sebanyak 23 orang dengan menggunakan teknik total sampling Analisis data dilakukan menggunakan analisis univariat, bivariat (Chi-Square) pada taraf signifikansi $\alpha \quad 0,5$ atau $95 \%$.

\section{Hasil Penelitian}

Hasil penelitian berdasarkan kajian di Rumah Sakit Tk II Putri Hijau, dengan statistik uji univariat dan bivariat

Hasil uji statistik univariat didapatkan bahwa berdasarkan pengkategorian sub variabel pengetahuan tentang APD yang paling besar berada pada kategori kurang yaitu sebanyak 13 orang $(56,5 \%)$ dan selebihnya berada pada kategori baik sebanyak 10 orang $(43,5 \%)$ dan Sub variabel sikap menunjukan yang paling besar berada pada kategori baik yaitu sebanyak 15 orang $(65,2 \%)$ dan selebihnya berada pada kategori kurang sebanyak 8 orang $(34,8 \%)$. Dan variabel tindakan pencegahan menujukan bahwa yang paling besar berada pada kategori baik yaitu sebanyak 13 orang $(56,5 \%)$ dan selebihnya berada pada kategori kurang sebanyak 10 orang $(43,5 \%)$

Berdasarka hasil uji bivariat dengan statistik uji Chi-Square menunjukan: Terdapat hubungan pengetahuan tentang APD dengan tindakan pencegahan infeksi di Ruang ICU Rumah Sakit Tk II Putri Hijau $(p=0,024<0,05)$. Terdapat hubungan sikap dengan tindakan pencegahan infeksi di Ruang ICU Rumah Sakit Tk II Putri Hijau $(\mathrm{p}=0,026<0,05)$.

\section{Hubungan Pengetahuan Perawat tentang APD dengan Tindakan Pencegahan Infeksi di Ruang ICU Rumah Sakit Tk II Putri Hijau}

Dari uji chi-square menunjukan bahwa ada hubungan antara pengetahuan perawat tentang Alat Pelindung Diri (APD) dengan tindakan pencegahan infeksi, hal ini dapat dilihat nilai $\mathrm{p}=$ $0,024<\alpha=0,05$. Karena semakin tinggi tingkat pengetahuan seseorang maka akan tahu tentang tindakan yang harus dilakukannya dalam hal ini tindakan untuk mencegah terjadinya infeksi baik terhadap perawat itu sendiri maupun terhadap pasien. Dari hasil analisa univariat didapat bahwa perawat yang telah melakukan tindakan pencegahan infeksi yaitu 56,5\%. Menurut Notoatmodjo (2007) Pengetahuan merupakan hasil dari tahu dan terjadi setelah orang melakukan penginderaan terhadap suatu objek tertentu. Pengindraan meliputi penglihatan, pendengaran, penciuman, rasa dan raba. Pengetahuan merupakan bagian dari perilaku yang tidak bisa diamati secara langsung oleh orang lain karena masih terjadi didalam diri manusia itu sendiri (covert behavior).

Hasil penelitian ini sesuai dengan penelitian Ningsih (2013) yang menemukan bahwa terdapat hubungan antara tingkat pengetahuan dan motivasi perawat dengan perilaku pencegahan infeksi nosokomial di Rumah Sakit Umum Daerah Sukoharjo.

Hubungan Sikap Perawat tentang APD denganTindakan Pencegahan Infeksi di ruang ICU Rumah sakit Tk II Putri Hijau

Dari hasil analisa uji univariat sikap perawat ruang ICU Rumkit TK II Putri Hijau pada umumnya baik 15 orang $(65,2 \%)$. Hal ini menunjukan sikap dalam pencegahan infeksi nosokomial baik. Sikap positif ini akan berpengaruh terhadap perubahan sikap yang lebih baik melalui pengamatan dan penilaian modal peran sikap perawat yang baik, sehingga sikap yang baik diterapkan dan akan memberikan manfaat ke pasien pada penyembuhan. Menurut Alport (1954) yang dikutip oleh Notoatmodjo (2007) bahwa sikap mempunyai 3 komponen pokok yaitu: kepercayaan (keyakinan), ide dan konsep terhadap suatu objek, Kehidupan emosional atau evaluasi terhadap suatu objek dan Kecenderungan untuk bertindak (tend to behave). 
Selain sikap yang baik dalam penelitian ini juga masih ditemukan 8 orang perawat $(34,8 \%)$ yang memiliki sikap kurang baik dalam hal penggunaan APD akan berdampak pada tindakan pencegahan infeksi, sikap yang kurang baik dalam pengguaan APD kemungkinan diakibatkan oleh kurangnya pengetahuan tentang manfaat APD dan perilaku pencegahan yang tidak sesuai dengan Standar precaution yang diterapkan oleh Depkes RI tentang prosedur dasar yang harus diterapkan guna memberikan perlindungan bagi tenaga kesehatandalam hal ini perawat maupun klien dan upaya pencegahan terjadinya infeksi. Penerapan Standar precaution terdiri dari beberapa tindakan salah satunya yaitu penggunaan Alat Pelindungan Diri (APD) sebagai upaya perlindungan utama bagi tenaga kesehatan.

Dari hasil uji bivariat dengan menggunakan uji statistik Chi-square pada taraf kemaknaan 95\% didapatkan hasil $\rho=0,026<\alpha=0,05$ hal ini menunjukan bahwa terdapat hubungan sikap perawat tentang APD dengan tindakan pencegahan infeksi di ruang ICU Rumah Sakit TK II Putri Hijau. Sikap yang baik dengan didukung oleh pengetahuan yang baik akan menjadi motivasi bagi perawat di ruang ICU untuk melakukan tindakan pencegahan infeksi. Hasil penelitian ini sesuai dengan penelitian Daeli (2013) tentang hubungan tingkat pengetahuan, sikap, tindakan dan masa kerja dengan pencegahan infeksi nosokomial, didapatkan hasil yang signifikan dari keempat variebel dengan nilai $\rho$-value sebagai berikut : tingkat pengetahuan $\rho=0,01$, Sikap $\rho=0,038$, tindakan $\rho=0,001$ dan masa kerja $\rho=0,04$ bila dibandingkan dengan $\alpha=0,05$. Hal ini juga sesuai dengan penelitian Salawati, Taufik dan Putra ()

\section{Simpulan}

Berdasarkan hasil penelitian yang dilakukan di Ruang ICU Rumah Sakit Tk II Putri Hijau kesimpulan :

Secara keseluruhan dari dua variabel yang diteliti yaitu pengetahuan dan sikap tentang APD secara signifikan memiliki hubungan dengan tindakan pencegahan infeksi di Ruang ICU Rumah Sakit Tk II Putri Hijau. Variabel yang memiliki hubungan yang lebih kuat dengan tindakan pencegahan infeksi di Ruang ICU Rumah Sakit Tk II Putri Hijau yaitu pengetahuan tentang APD dengan nilai $\rho$ sebesar 0.024 lebih kecil dari $\alpha 0,05(\rho=0,024>\alpha=0,05)$.

\section{Saran}

1. Manajemen rumah sakit disarankan untuk meningkatkan pengetahuan perawat ICU tentang manfaat alat pelindung diri dalam melaksanakan tindakan pencegahan infeksi di rumah sakit, dan memiliki sarana Alat pelindung diri yang lengkap sesuai dengan risiko penularan infeksi yang mungkin timbul.

2. Melaksanakan pelatihan secara rutin yang berkaitan dengan upaya-upaya pencegahan infeksi di rumah sakit

\section{Daftar Pustaka}

Aditama. 2006. Kesehatan dan Keselamatan Kerja. UI. Press. Jakarta.

Anonim. Faktor Keselamtan dan Kesehatan Kerja (K3) Terhadap Infeksi Nosokomial.(Jurnal Elektronik) diakses tanggal $20 \quad$ Pebruari 2016. http://rifqinubairi.blogspot.com

Depkes RI. 2003. Pedoman pelaksanaan kewaspadaan universal di pelayanan kesehatan. Jakarta.

RI. 2007. Pedoman Manajemen K3 di Rumah Sakit.

Habni. Y, 2009. Prilaku Perawat Dalam Pencegahan Infeksi Nosokomial di Ruangan Rindu A, Rindu B, ICU, IGD, Rawat Jalan di Rumah Sakit Umum Pusat Haji Adam Malik Tahun 2009, Skripsi PSIK USU, Medan.

Hidayat, Alimuldan Aziz, 2007. Metode penelitian kebidanan dan teknik analisa data. Salemba. Jakarta.

Kathryn, A. 2004. Phlebotomy technician specialist. (2nd. ed) Clifton Park: Delmar.

Maja, TMM. 2009. Precaution use by occupational health nursing students during clinical placement. Adeliade : Tswane University Of Technology.

Musadad, D.A. 1993. Sanitasi Rumah Sakit Sebagai Investasi. Cermin Dunia Kedokteran No. 83.

Nasution, S.A. 2011. Perbedaan Sanitasi Lingkungan Dan Prilaku Petugas Kesehatan Di Ruangan ICU RSUD dr. Pirngadi Dan Rumkit TK II Putri Hijau Kesdam I/BB Medan Tahun 2010, Tesis FKM USU, Medan.

Ningsih,EW.2013. Hubungan Tingkat antara Pengetahuan dan motivasi perawat dengan perilaku Pencegahan Infeksi Nosokomial di rumah sakit Umum Daerah Sukoharjo (Jurnal Elektronik) dikases 24 Pebruari 2016 ; Http:/www. ums.ac.id 
Notoatmodjo Soekidjo, 2007. Promosi Kesehatan dan Ilmu Prilaku. Jakarta. Rineke Cipta.

Nursalam \& Ninuk, 2007. Asuhan Keperawatan Pada Pasien Terinfeksi. Jakarta. Salemba Medika.

Potter, P. A, Perry, A.G. 2005. Fundamental of nursing: concepts, process, and practice, 4/E. Philadelphia: Mosby

Purba, R. B. 2010. Gambaran Perilaku Pemakaian APD dan Gejala Keracunan pada Penyemprotan Pestisida Di Afdeling V dan VI Kebun Dolok Ilir PTPN IV. Skripsi PSKM USU, Medan.

Purwanto H, (1998) pengantar Perilaku Manusia untuk keperawatan. Jakarta. EGC.

Putra. M.U.K, 2012. Hubungan Tingkat Pengetahuan dan Sikap Dengan Perilaku Penggunaan Alat Pelindung Diri Pada Mahasiswa Profesi Fakultas Ilmu Keperawatan. Universitas Indonesia.
Rosdahl, C Bunker, Merry, T. Kowalski (2008). Textbook Of Basic Nursing (9th ed). Philadelphia. Lipponcott.

Swearing, (2000). Buku keperawatan Medical bedah edisi 2, Jakarta: EGC

Tietjen dkk, 2004. Panduan Pencegahan infeksi nosokomial untuk fasilitas pelayanan kesehatan dengan sumber daya terbatas. Jakarta. YBP-SP.

Tim Nuansa Aulia, 2010 Himpunan peraturan dan perundang-undangan tentang Rumah Sakit. Bandung. Nuansa Aulia.

Wawan dan Dewi. 2010.Teori dan Pengukuran Pengetahuan, Sikap dan Prilaku Manusia. Nuha Medika; Yogyakarta.

WHO. 2004. Practical guaidelines for infection control in health care facility. India : WHO Regional Office South East Asia 
